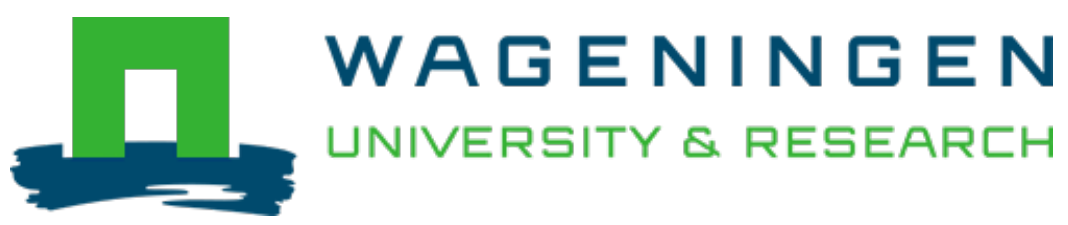

\author{
Nutritional characteristics of mung bean foods \\ British Food Journal \\ Dahiya, P.K.; Nout, M.J.R.; Boekel, M.A.J.S.; Khetarpaul, N.; Grewal, R.B. et al \\ https://doi.org/10.1108/BFJ-11-2012-0280
}

This publication is made publicly available in the institutional repository of Wageningen University and Research, under the terms of article $25 \mathrm{fa}$ of the Dutch Copyright Act, also known as the Amendment Taverne. This has been done with explicit consent by the author.

Article $25 \mathrm{fa}$ states that the author of a short scientific work funded either wholly or partially by Dutch public funds is entitled to make that work publicly available for no consideration following a reasonable period of time after the work was first published, provided that clear reference is made to the source of the first publication of the work.

This publication is distributed under The Association of Universities in the Netherlands (VSNU) 'Article $25 \mathrm{fa}$ implementation' project. In this project research outputs of researchers employed by Dutch Universities that comply with the legal requirements of Article $25 \mathrm{fa}$ of the Dutch Copyright Act are distributed online and free of cost or other barriers in institutional repositories. Research outputs are distributed six months after their first online publication in the original published version and with proper attribution to the source of the original publication.

You are permitted to download and use the publication for personal purposes. All rights remain with the author(s) and / or copyright owner(s) of this work. Any use of the publication or parts of it other than authorised under article $25 \mathrm{fa}$ of the Dutch Copyright act is prohibited. Wageningen University \& Research and the author(s) of this publication shall not be held responsible or liable for any damages resulting from your (re)use of this publication.

For questions regarding the public availability of this publication please contact openscience.library@wur.nl 


\section{Nutritional characteristics of mung bean foods}

\section{Pradeep Kumar Dahiya, M.J.R. Nout and Martinus A. van Boekel} Department of Agrotechnology and Food Sciences, Wageningen University, Wageningen, The Netherlands

Neelam Khetarpaul

Department of Foods \& Nutrition, CCS Haryana Agricultural University, Hisar, India

Raj Bala Grewal

Centre of Food Science \& Technology, CCS Haryana Agricultural University, Hisar, India, and

Anita Linnemann

Department of Agrotechnology and Food Sciences, Wageningen University, Wageningen, The Netherlands
Received 21 November 2012 Revised 13 May 2013 Accepted 20 May 2013

\begin{abstract}
Purpose - The purpose of this paper is to address malnourishment in developing countries by a food-based approach in which locally produced and consumed foods are improved by applying food processing techniques that benefit the amount and availability of desirable nutrients.

Design/methodology/approach - To facilitate this approach, this paper reports on the composition and in vitro micronutrient accessibility of 14 traditional mung bean foods from India in relation to their preparation methods.

Findings - Proximate composition, in vitro mineral accessibility, phytic acid and polyphenol contents varied among the range of products. Products requiring either fermentation or germination, had higher in vitro iron, zinc and calcium accessibility. Average in vitro iron, zinc and calcium accessibility of the mung bean products were 16,9 and $418 \mathrm{mg} \mathrm{kg}^{-1}$ dry weight. Phytic acid and polyphenols averaged 2.1 and $1.8 \mathrm{~g} \mathrm{~kg}^{-1}$ dry weight, respectively, and were negatively correlated with in vitro mineral accessibility.

Practical implications - Different mung bean products ( $100 \mathrm{~g}$ ) cover 12.0-59.5, 5.2-45.6, 4.2-28.6 and 1.1-7.1 per cent of the recommended dietary allowance for protein, iron, zinc and calcium, respectively, for seven- to nine-year-old Indian children.

Originality/value - This study demonstrated the wide range of traditional mung bean foods in India and presents options to tackle malnourishment by a food-based approach.

Keywords Calcium, In vitro mineral accessibility, Iron, Phytate, Polyphenols, Zinc

Paper type Research paper

\section{Introduction}

Malnutrition is a serious health concern in many developing countries. A major cause is lack of access to nutritious food products. Strategies to tackle malnutrition are fortification of food products and distribution of nutrient supplements, but a
\end{abstract}

The authors gratefully acknowledge the financial support from the Department of Biotechnology, Ministry of Science and Technology, Government of India, from Wageningen University through the Interdisciplinary Research and Education Fund (INREF) via the TELFUN programme and from the International Foundation of Science (IFS) (Grant No. - A E/ 21294).

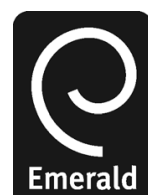

British Food Journal Vol. 116 No. 6, 2014 pp. $1031-1046$

(C) Emerald Group Publishing Limited $0007-070 \mathrm{X}$ DOI 10.1108/BFJ-11-2012-0280 
$\mathrm{BFJ}$ 116,6

1032 food-based approach has the advantage that it is within easy reach, as indigenous foods provide variety, are well accepted, frequently consumed and readily available.

Among the indigenous foods, mung bean-based products are widely consumed in India. Mung bean or green gram (Vigna radiata (L.) R. Wilczek) has been cultivated in India since prehistoric times and is believed to be a native crop of India. Its grains have a protein content comparable to that of chick pea (Cicer arietinum L.) and contain less anti-nutritional (Chitra et al., 1995) and flatulence causing compounds than soya bean (Glycine max (L.) Merr.) (Abdullah et al., 1984). Mung bean is used in India for the preparation of different food products like dhals, sweets, snacks and savoury products. The frequency of consumption of different mung bean products is very high (Grover et al., 2004; Manu and Khetarpaul, 2006), thus offering the possibility for improved products to contribute significantly to the nutritional status of the local people.

Although the nutritional composition of raw mung bean grains of different varieties has been documented (Dahiya et al., 2014), little or no information is available on the proximate, mineral and anti-nutritional composition of the indigenous mung bean food products. Therefore, in the present investigation mung bean food products were analysed to determine the nutritional and anti-nutritional components and their relation with each other. This paper is the first to report on the major mung bean foods of north India and on their nutritional potential.

\section{Material and methods}

Sampling of mung bean food products

Mung bean food products were collected from rural and urban households or purchased from the market in Hisar district of Haryana state in India. Five samples of approximately $250 \mathrm{~g}$ of each product were collected or purchased from the different regions where the foods are known to be representatively processed and consumed. Each sample was collected as ready to eat or ready to cook. In the case of ready to cook products, they were cooked in the laboratory. Food products collected were analysed individually and not with the other products with which they are consumed in a meal. The five samples of food products were then pooled to minimise variation to form one composite food sample. After thorough mixing of the composite sample using a blender for $2 \mathrm{~min}$, three representative portions of each were removed and weighed. The dried samples were ground to fine powder in an electric grinder (Cyclotec $\mathrm{M} / \mathrm{s}$ Tecator, Hoganas, Sweden) and passed through a $0.5 \mathrm{~mm}$ mesh sieve. Powders were sealed and stored in air-tight plastic containers in a refrigerator at $5^{\circ} \mathrm{C}$ until analysis (maximum 20 days).

\section{Analytical methods}

Proximate composition. The following AOAC (1990) methods were used to determine proximate composition: drying at $105^{\circ} \mathrm{C}$ for $24 \mathrm{~h}$ for moisture (AOAC 925.10), incineration at $550^{\circ} \mathrm{C}$ for ash (AOAC 923.03), defatting in a Soxhlet apparatus using hexane for crude lipids (AOAC 920.39), digestion with $\mathrm{NaOH}$ and $\mathrm{H}_{2} \mathrm{SO}_{4}$ for crude fibre (AOAC 962.09) and the microKjeldahl method for crude protein (AOAC 960.52). For conversion of nitrogen to crude protein, a conversion factor of 6.25 was used. The carbohydrate content was estimated by difference of protein, fibre, ash and fat. Energy was calculated using Atwater energy conversion factors of $4.0,4.0$ and $9.0 \mathrm{kcal} \mathrm{g}^{-1}$, for protein, carbohydrate and fat, respectively, and recalculated to $\mathrm{kJg}^{-1}$. Proximate composition was determined using dried samples. 
Mineral composition. Calcium, iron and zinc contents were determined by first digesting $1 \mathrm{~g}$ of sample using $25 \mathrm{ml}$ diacid mixture $\left(\mathrm{HNO}_{3} / \mathrm{HClO}_{4}: 5 / 1, \mathrm{v} / \mathrm{v}\right)$ after which the digested solution was filtered through Whatman No. 42 filter paper. The volume of the solution was made up to $50 \mathrm{ml}$ and then the mineral content was determined by an Atomic Absorption Spectrophotometer 2380 (Perkin-Elmer, USA) using the method of Lindsay and Norwell (1978).

In vitro mineral accessibility. In vitro iron accessibility was determined by the single enzyme method according to Rao and Prabhavathi (1978). This method is convenient, requires a minimum of chemicals, and is well suited for comparative purposes. Obviously, it does not necessarily predict exactly what will happen in vivo, but neither do the more sophisticated in vitro approaches. The method involved incubation of $2 \mathrm{~g}$ of powdered sample with $25 \mathrm{ml}$ of $5 \mathrm{~g}^{-1}$ pepsin in $0.1 \mathrm{~N} \mathrm{HCl}$ solution in a water bath of $37^{\circ} \mathrm{C}$ for $90 \mathrm{~min}$, after adjusting the $\mathrm{pH}$ to 1.3 using $\mathrm{HCl}$. The mixture was then centrifuged at $3,000 \mathrm{rpm}$ for $45 \mathrm{~min}$ and the supernatant was filtered through Whatman No. 44 filter paper. Iron in the filtrate was determined according to the AOAC (1995) method by treating with $1 \mathrm{ml}$ hydroxylamine hydrochloride solution and $5 \mathrm{ml}$ acetate buffer solution and then reacted with $\alpha, \alpha^{\prime}$ dipyridyl to yield a colour which was read at $510 \mathrm{~nm}$ and used to make a calibration line for calculating the in vitro iron accessibility.

In vitro zinc and calcium accessibility were assessed with the multiple enzyme method of Kim and Zemel (1986). The method involved hydration of $2 \mathrm{~g}$ sample with $3 \mathrm{ml}$ distilled water. Hydrated samples were then treated with $20 \mathrm{ml}$ pepsin solution $\left(1 \mathrm{~g}^{-1}\right.$ pepsin in $\left.0.1 \mathrm{~N} \mathrm{HCl}\right)$. Next the $\mathrm{pH}$ was adjusted to 1.5 , followed by incubation at $37^{\circ} \mathrm{C}$ for $1 \mathrm{~h}$ in a controlled temperature chamber with shaker. After incubation the $\mathrm{pH}$ was raised to 6.8 with $\mathrm{NaOH}$ and $2.5 \mathrm{ml}$ of a suspension containing $5 \mathrm{~g}^{-1}$ pancreatin and $50 \mathrm{~g} 1^{-1}$ bile was added and again incubated for $1 \mathrm{~h}$ at $37^{\circ} \mathrm{C}$ in a controlled temperature chamber with shaker. Next, the volume was increased to $50 \mathrm{ml}$ with distilled water and immediately centrifuged at $3,000 \mathrm{rpm}$ for $45 \mathrm{~min}$ at $5^{\circ} \mathrm{C}$. Supernatants were removed and again centrifuged at $13,000 \mathrm{rpm}$ for $45 \mathrm{~min}$ at $5^{\circ} \mathrm{C}$. The supernatant was digested with diacid mixture $\left(\mathrm{HNO}_{3} / \mathrm{HClO}_{4}: 5 / 1, \mathrm{v} / \mathrm{v}\right)$ and then dissolved calcium and zinc were determined by an Atomic Absorption Spectrophotometer 2380 (Perkin-Elmer, USA) using the method of Lindsay and Norwell (1978).

Phytic acid and polyphenol content. Phytic acid (PA) was estimated colorimetrically by the method of Davies and Reid (1979), by incubating $500 \mathrm{mg}$ of sample with $20 \mathrm{ml}$ of $0.5 \mathrm{M} \mathrm{HNO}_{3}$ for $3 \mathrm{~h}$ with continuous shaking. The suspension was then filtered through Whatman No. 1 filter paper; $1 \mathrm{ml}$ of this suspension was made up to $1.4 \mathrm{ml}$ using distilled water and then mixed with $1 \mathrm{ml}$ ferric ammonium sulphate solution containing $50 \mu \mathrm{g}$ of iron. The test tube containing this suspension was placed in boiling water for $20 \mathrm{~min}$. Next, the suspension was cooled to room temperature and $5 \mathrm{ml}$ iso-amyl alcohol was added followed by $0.1 \mathrm{ml}$ ammonium thiocyanate solution $\left(100 \mathrm{~g}^{-1}\right)$. The content was mixed well, and centrifuged at 3,000 rpm for $10 \mathrm{~min}$. Colour intensity in alcohol was read at $465 \mathrm{~nm}$ using a spectrophotometer and used to make a calibration line for calculating the phytic acid.

Total polyphenols were extracted from $500 \mathrm{mg}$ of defatted sample by refluxing with $50 \mathrm{ml}$ methanol containing $10 \mathrm{gl}^{-1} \mathrm{HCl}$ for $4 \mathrm{~h}$. The extract was concentrated by evaporating methanol on a boiling water bath and brought to $25 \mathrm{ml}$ with methanol-HCl solution (Singh and Jambunathan, 1981); $0.5 \mathrm{ml}$ of extract was made up to $8.5 \mathrm{ml}$ with distilled water, mixed with $0.5 \mathrm{ml}$ Folin Denis reagent and shaken. After $3 \mathrm{~min}$, 
BFJ 116,6

1034
$1 \mathrm{ml}$ of saturated sodium carbonate was added, followed by shaking. After an hour, the absorbance was read at $725 \mathrm{~nm}$. Calculations were done using absorbance and expressed as tannic acid equivalent (Swain and Hills, 1959). The PA:Zn, PA:Ca and PA:Fe molar ratios were calculated by the method of Wyatt and Triana-Tejas (1994).

Pepsin, pancreatin, pancreatic amylase and bile were obtained from Sigma-Aldrich Co., USA. All other reagents used for the analyses were of analytical grade and glassware was acid $\left(10 \mathrm{gl}^{-1} \mathrm{HCl}\right)$ washed.

Statistical analysis. Each composite sample of mung bean product was analysed in triplicate. Mean \pm standard deviation values were calculated. Comparison of means was performed by one-way analysis of variance (ANOVA) followed by Tukey multiple comparison test. Significance was accepted at $p<0.05$ (Panse and Sukhatme, 1961). Pearson linear correlation coefficients were determined to relate the nutrient digestibility and accessibility with concentrations of anti-nutritional factors. All statistical analyses were performed with PASW Statistics (Version 18.0.2) IBM Co., USA.

\section{Results and discussion}

Description of the products

Table I presents a brief description of the mung bean products and their major ingredients. They were classified into four groups, namely dhals, sweets, snacks and others. Dhals are spiced curries of whole or split legumes, with thick soup-like consistency, commonly consumed with cereal products like rice and chapattis (Indian flat bread). Sweets include three types of products like laddu, burfi and halwa, prepared with ghee (clarified butter oil) and sugar along with dehulled split mung bean by shallow frying the mung bean flour or paste. Snacks are salted or spiced products like namkeen, papad, bhalle and pakore. Namkeen are deep fried spiced dehulled split mung bean grains. Papad is a spiced flat roasted product of dehulled split mung bean. Bhalle are round balls of deep fried dehulled fermented mung bean paste. Wadian, sprouts and khichadi products each have distinctive characteristics and thus were combined as a category of other products. Wadian are irregular shaped sun-dried dumplings of fermented dehulled mung bean paste, which are cooked with spices. Sprouts are germinated mung bean grains eaten as such or fried to be used in salads. Khichadi is prepared by cooking split mung beans with white rice.

\section{Proximate composition}

The composition of the mung bean foods is presented in Table II. Among the mung bean products, moisture content varied significantly $(p<0.05)$. The highest moisture content was found in dhals, bhalle, wadian and khichadi. The soup-like consistency of dhals and the soaking before bhalle consumption explain their relatively high moisture content. Sweets like whole laddu, dehulled split laddu and halwa contained less moisture with the least moisture in burfi, that has high amounts of fat due to the addition of ghee. Halwa contained most fat followed by burfi. Among the snacks, namkeen and pakore had fat contents comparable to that of sweets like whole laddu and dehulled split laddu; this can be explained as namkeen and pakore are deep fried, resulting in oil absorption, whereas both types of laddu contain ghee as an ingredient. Dhals, papad, bhalle and wadian are low in crude fat with the lowest content in sprouts and khichadi. The relatively low fat content of dhals can be attributed to the use of only small amounts of oil to sauté spices and condiments as well as to the absence of frying as a processing method. Bhalle contains less fat than pakore, despite the fact that both 


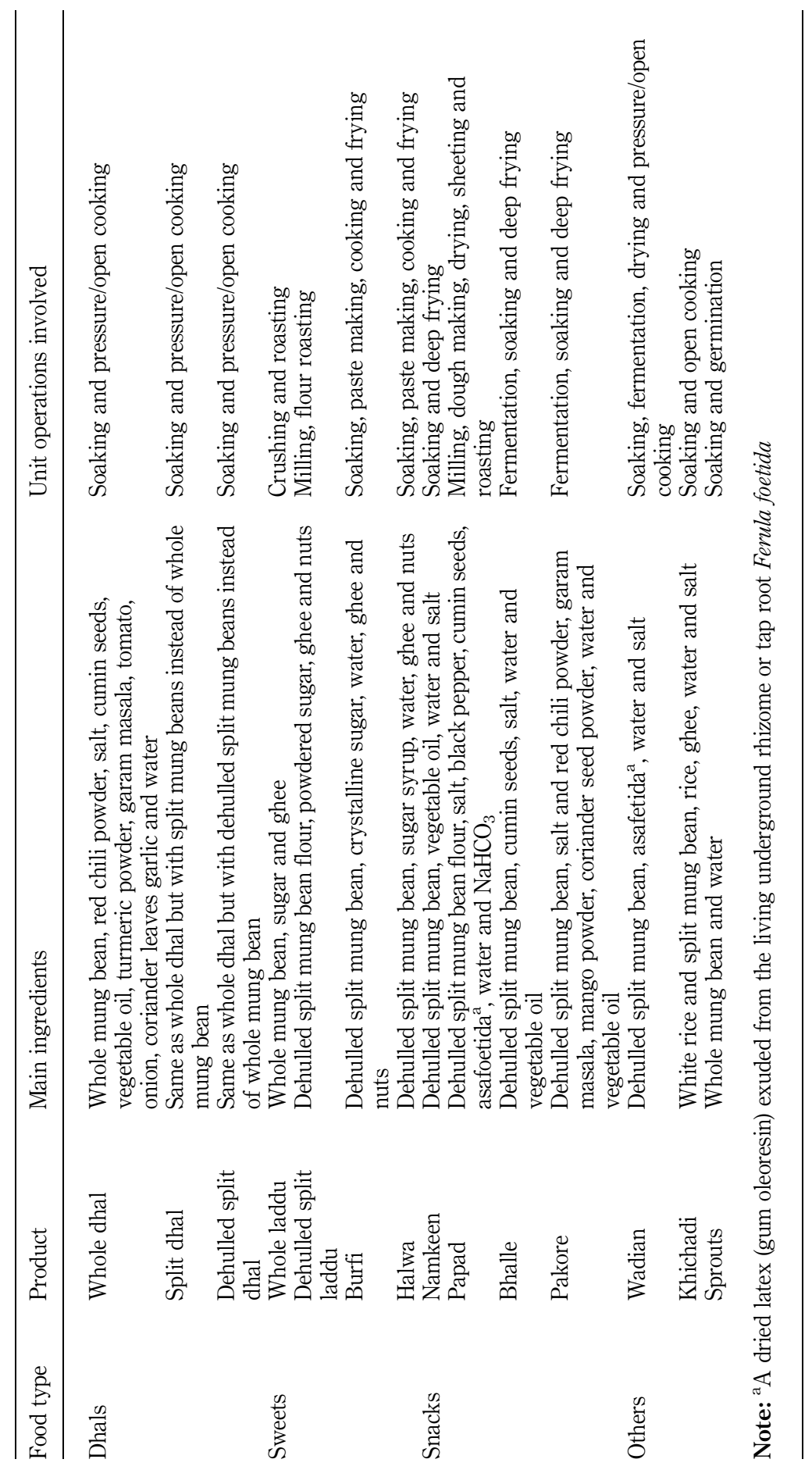

Mung bean
foods

1035

Table I.

Mung bean derived foods and summary of their preparation 
$\mathrm{BFJ}$

116,6

\section{6}

Table II.

Proximate composition of mung bean derived foods
กิ่ $4+1+1+1+1+1+1+1+1+1+1+1+1+1$

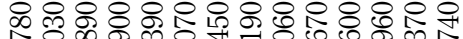

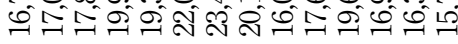

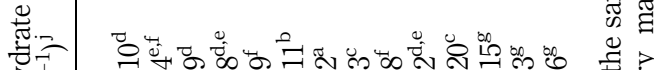
$+1+1+1+1+1+1+1+1+1+1+1+1+1+1$

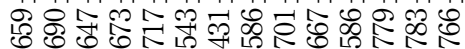

告 กิ ลี $+1+1+1+1+1+1+1+1+1+1+1+1+1+1$

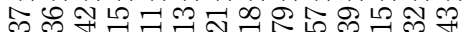

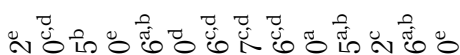
$+1+1+1+1+1+1+1+1+1+1+1+1+1+1$

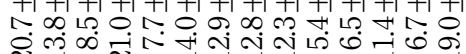

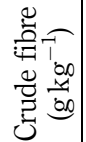

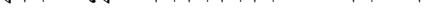

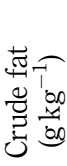

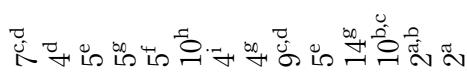
$+1+1+1+1+1+1+1+1+1+1+1+1+1+1$

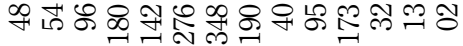

必

피

焉 苨加

胥 $1+1+1+1+1+1+1+1+1+1+1+1+1+1+1$
15

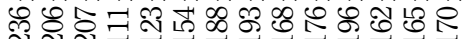

. 용용

T V 密 $+1$

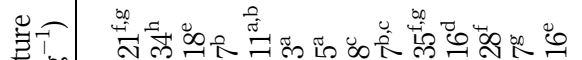
$+1+1+1+1+1+1+1+1+1+1+1+1+1+1$

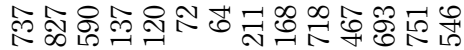

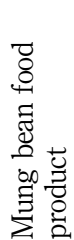

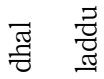

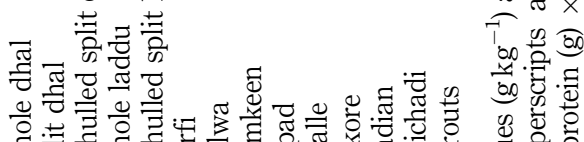

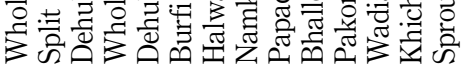

离

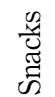

产 
are fried products; bhalle is soaked in water for two to six hours before consumption which might expel some fat from the product. Wadian and papad are not fried and also do not contain a lot of fat as an ingredient, which explains why their fat content is lower than that of the sweets.

Dhals contain slightly more crude protein than other products, with the lowest amounts in whole laddu and dehulled split laddu. Crude protein contents of the products ranged from 111 to $236 \mathrm{~g} \mathrm{~kg}^{-1}$ dry weight. Crude protein content of snacks showed no significant difference when compared with wadian, khichadi and sprouts. It seems that processing methods had no effect on the crude protein content.

Crude fibre was highest in whole $d h a l$, whole laddu and sprouts, which are made primarily of whole mung bean grains, whereas bhalle, pakore, khichadi, dehulled split laddu and dehulled split dhal had lower crude fibre contents. The latter products are made of dehulled split mung beans in which the majority of the fibre is removed as husk.

The ash content of mung bean products containing hull, like whole dhal, split dhal and sprouts, was higher than in sweets made of dehulled split mung beans. Papad had the highest ash content although it is made from dehulled split mung beans; this may be caused by the use of black pepper as an ingredient, as it contains a considerable amount of ash (40-50 $\left.\mathrm{g} \mathrm{kg}^{-1}\right)$ (Parthasarathy et al., 2008). Moreover, use of asafoetida (a dried latex, gum oleoresin, exuded from the living underground rhizome or tap root Ferula foetida) may also have contributed to the relatively high ash content of papad as asafoetida contains $50 \mathrm{~g} \mathrm{~kg}^{-1}$ of ash (Pradeep et al., 1993). Khichadi contained a considerable amount of ash; here the main contribution is due to the rice and not to the dehulled split mung bean. Fatty products like sweets, namkeen and pakore, contained slightly less carbohydrate than the other products. Fatty products like burfi, halwa, laddu and namkeen provide the highest amounts of calories compared to products like papad, wadian, khichadi and sprouts, that are non-fried nod non-fatty products.

\section{Mineral composition}

Table III presents iron, zinc and calcium in the different mung bean foods. The highest mineral concentrations were found for calcium, while iron and zinc were present in lower amounts. There are statistically significant differences between the mineral levels of the mung bean products. The variation in mineral content in products may have several reasons, like the use of whole, split or dehulled split mung bean, or the type of processing, like soaking, which results in loss of minerals. Dhals had higher mineral contents than halwa, laddu and burfi, due to the use of various spices, condiments, tomato and onion as ingredients. Bhalle had the highest iron content followed by dhals; the contents are comparable to previous studies (Pushpanjali and Khokhar, 1995). Less iron and zinc is present in papad despite it having the highest ash content. This may be due to the fact that the minerals are determined as elements and the ash contains their salts. Moreover, ash may also contain other elements like sodium and magnesium, which were not determined. Products involving germination, dehulling and fermentation as unit operations, like sprouts, bhalle and dhals, had higher iron contents. Calcium contents were higher in dehulled split dhal, dehulled split laddu, papad and khichadi.

Phytic acid and polyphenols

Phytic acid and polyphenol contents of mung bean products are presented in Table IV. Phytic acid content varied considerably among the various mung bean products. 


\section{$\mathrm{BFJ}$ 116,6}

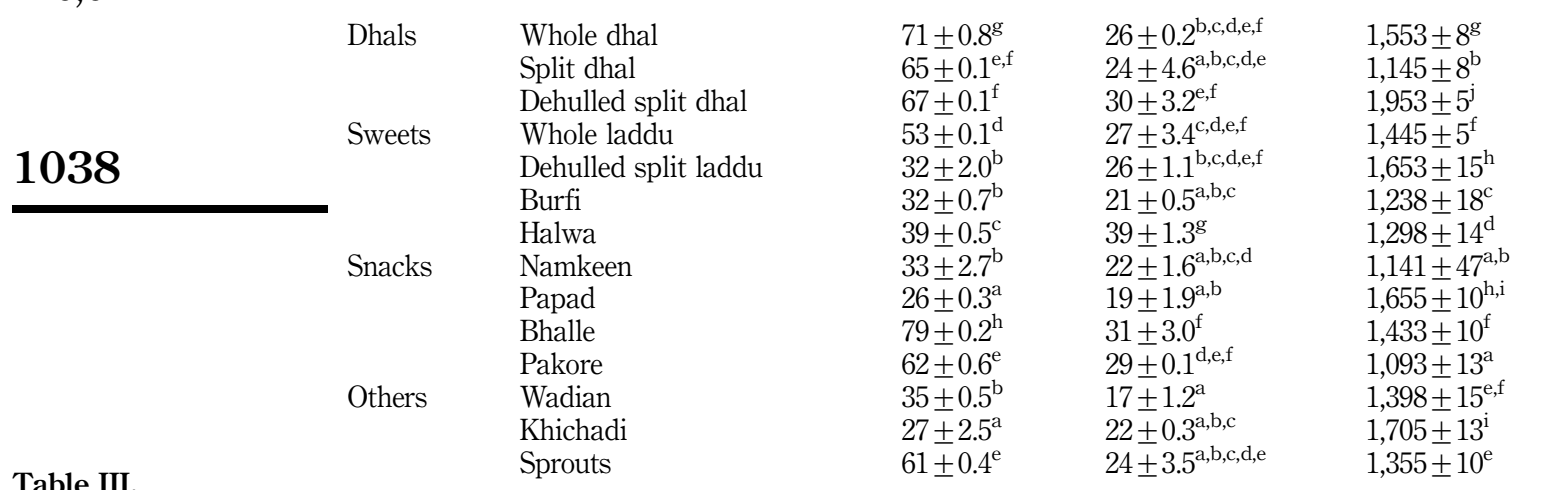

Table III.
Mineral composition of mung bean derived foods
Notes: Values ( $\mathrm{mg} \mathrm{kg}^{-1}$ dry matter) are expressed as mean \pm standard deviation $(n=3)$. Means in the same column with the different superscripts are significantly different at $p<0.05$
Table IV.

Phytic acid, polyphenol and molar ratios of phytic acid to minerals of mung bean derived foods
Food type $\quad$ Mung bean food product $\quad$ Iron $\left(\mathrm{mg} \mathrm{kg}^{-1}\right) \quad$ Zinc $\left(\mathrm{mg} \mathrm{kg}^{-1}\right) \quad$ Calcium $\left(\mathrm{mg} \mathrm{kg}^{-1}\right)$

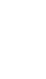




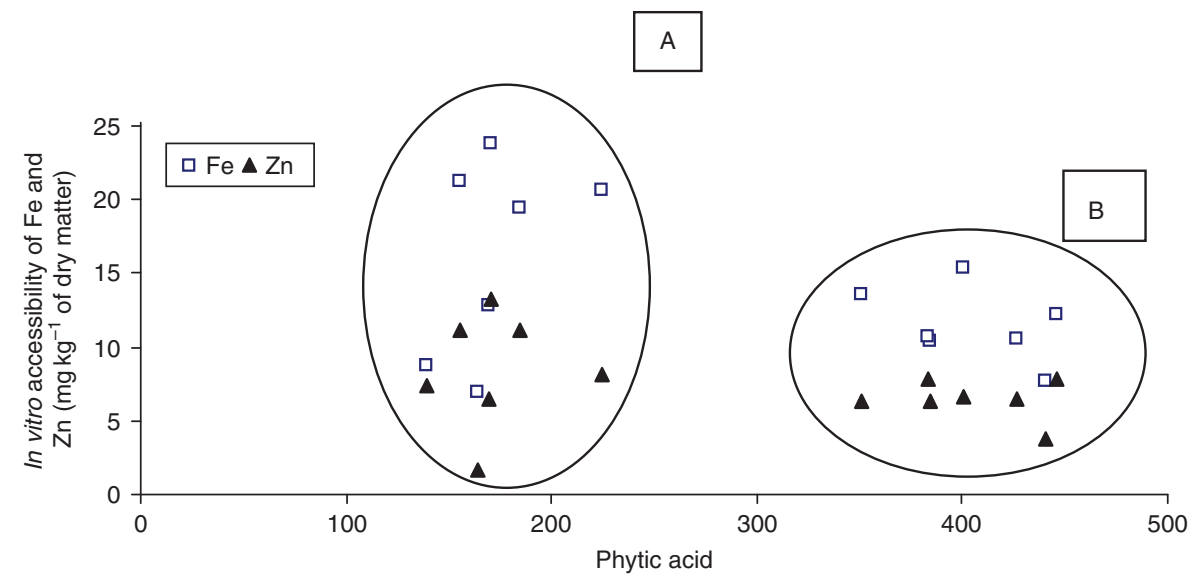

Note: A and B depict two distinct categories of products based on anti-nutrient composition
Mung bean foods

products processed by cooking and soaking. The results seem to indicate that the degrading impact of dehulling, germination and fermentation on the phytic acid content of mung bean products results in lower phytic acid contents (Jood et al., 1998). However, as the production of these products involves more than one processing step, it is not clear which processing step has the most degrading impact on the phytic acid. The relatively high phytic acid content of sweets, despite the fact that they are made of dehulled split mung bean, can be attributed to two factors. First, sweets are prepared only with sugar, ghee and dehulled split mung bean, in other words, there is no dilution of phytic acid by the addition of significant amounts of other ingredients that are low in phytic acid. Second, sweets also contain nuts, like cashews and almonds, which also contain phytates ranging from $1.5-3.5 \mathrm{~g} \mathrm{~kg}^{-1}$ of edible portion (Venkatachalam and Sathe, 2006). In contrast, dhals need a lower amount of mung bean to prepare and also involve soaking as a processing step, which is known to have a degrading effect on phytic acid (Sattar et al., 1989). The relatively high amount of phytic acid in khichadi could be due to the split mung bean used in its preparation instead of dehulled split mung bean.

Polyphenol was found to be higher in products prepared with whole mung bean grains, like whole and split mung bean dhal and whole laddu, as compared to sweets and snacks prepared with dehulled split mung bean dhal. This can be due to the fact that polyphenols are mainly present in the outer seed coat of the grain, which are removed during dehulling. The polyphenol content of fermented products, like bhalle and wadian, is lower than that of fried products like pakore. Khichadi contains the lowest amount of polyphenols, which may be due to the fact that only small amounts of mung bean are required for its preparation.

\section{In vitro mineral accessibility}

There is a significant difference in in vitro mineral accessibility of iron, zinc and calcium among products (Table V), which may be related to the presence of anti-nutrients such as phytic acid, polyphenols as well as dietary fibre, and to the contents of minerals themselves. There was a negative correlation of in vitro iron accessibility with phytic acid $\left(R^{2}=-0.72\right)$. The highest amount of in vitro accessible 


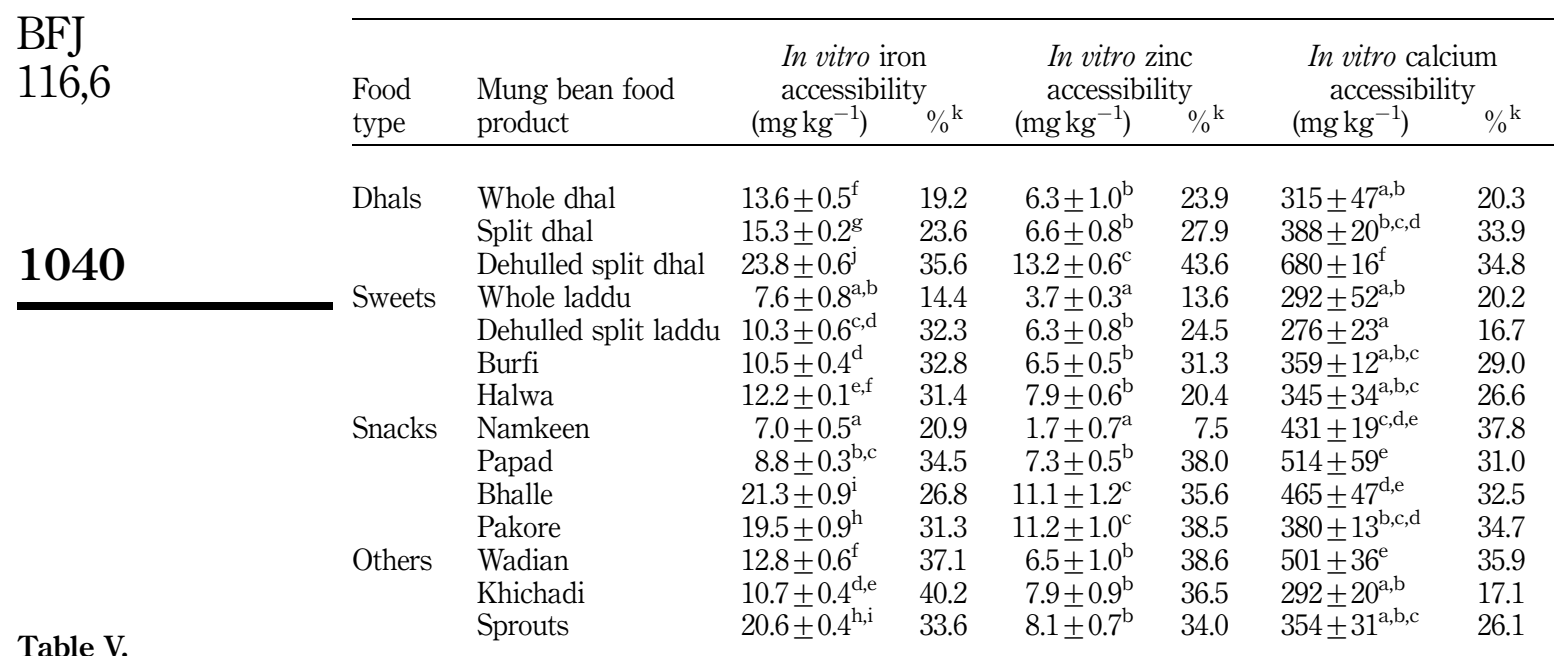

In vitro mineral accessibility of mung bean derived foods
Notes: Values are expressed as mean \pm standard deviation $(n=3)$ on dry matter basis. Means in the same column with the different superscripts are significantly different at $p<0.05$. ${ }^{\mathrm{k}_{0}} \%$, percentage of the content present

iron was found in dehulled split dhal followed by bhalle and sprouts, whereas whole laddu, namkeen and papad had the lowest in vitro accessible iron. Products involving fermentation and germination and dehulling as processing method have relatively higher in vitro accessible iron as compared to fried and fatty products. This may be due to degradation of phytic acid present in the testa of mung bean grains during the fermentation and germination processes (Barakoti and Bains, 2007). As most of the phytic acid is present in the hull of whole mung bean grains, dehulling reduces its amount (Ghavidel and Prakash, 2007), imparting a positive effect on in vitro iron accessibility in split dehulled dhal. Whole laddu and whole dhal had the lowest in vitro iron accessibility, which may be due to presence of phytic acid in the hull of whole mung bean grain used to prepare these products, which has an inhibitory effect on the in vitro iron accessibility. In vitro iron accessibility in the mung bean products is high in comparison to what is expected for iron absorption in human beings. The results show in vitro iron accessibility in the same range as found in different cereals and legume-based foods by previous authors (Rao and Prabhavathi, 1978). Moreover, it is expected that in vitro iron accessibility tends to increase at low $\mathrm{pH}$ values due to a greater extent of dissociation of the phytic-mineral complex.

Similarly, in vitro accessible zinc is highest in dehulled split dhal followed by the fermented product bhalle and the germinated product, sprouts. Whole mung bean products had significantly lower in vitro accessible zinc. In vitro accessible calcium was highest in dehulled split dhal followed by wadian and bhalle. The relatively high in vitro zinc accessibility in dehulled split dhal is due to the fact that dehulled grains contain less phytic acid than whole grains and thus have a lower inhibitory effect on bivalent ions like zinc (Ghavidel and Prakash, 2007). In vitro accessible calcium in snacks was considerably higher than in sweets and whole mung bean products (Crea et al., 2008). 
Phytic acid to mineral molar ratios (Table IV) are used as an indicator for the bioaccessibility of divalent mineral ions. The average PA:Fe, PA:Zn and PA:Ca of the mung bean products are 5.9, 11.5 and 0.13 , respectively. Critical values of molar ratios of phytic acid to a mineral for adequate mineral absorption have been reported as $<0.24$ for phytate/calcium (Morris and Ellis, 1980), $<1$ for phytate/iron (Hallberg et al., 1989) and <10 for phytate/zinc (Morris and Ellis, 1980). However, in mung bean products phytic acid to mineral molar ratios are quite high, whereas the percentage in vitro mineral accessibility is also unexpectedly high, which might be due to the fact that effect of phytic acid on minerals not only depends on the amount of phytic acid but also on the presence of in vivo iron absorption enhancers, like vitamin C (Davidsson et al., 2001) and the processing techniques used. Moreover, it has been reported that the effect of phytic acid on minerals is also governed by the $\mathrm{pH}$ (Crea et al., 2008). Mung bean products have lower phytic acid to mineral ratios as compared to raw mung bean (Dahiya et al., 2013), indicating the degradation effect of different processing methods on phytic acid. These ratios vary significantly among mung bean products, showing that products with lower phytic acid to mineral ratios have comparatively higher mineral accessibility. The values of PA:Ca are much lower than PA:Fe and PA:Zn due to the presence of higher amounts of calcium in the mung bean products. In vitro iron and zinc accessibility seem not to be affected by PA:Fe and PA:Zn in the mung bean products (Figure 2), indicating other possible factors like $\mathrm{pH}$, presence of other anti-nutritional components and minerals affecting in vitro mineral accessibility.

Therefore, in the case of mung bean foods, PA:Fe and PA:Zn cannot be effectively used to predict mineral bioavailability. If it is assumed that calcium binds more with phytic acid due to its large amounts and forms many phytic acid-calcium complexes, then this will create a sparing effect on the iron and zinc, as the concentration of calcium is higher than iron and zinc in the products. Figure 3 indicates the possible sparing action of phytic acid-calcium on the iron and zinc accessibility in the majority of mung bean products. However, it seems that in case of split mung bean dhal, whole laddu, burfi and halwa there is still enough phytic acid to bind with Fe and Zn. This is also evident from the fact that the percentage of in vitro iron and zinc accessibility is higher in mung bean products than the percentage in vitro calcium accessibility. Figure 4 indicates PA:Ca as potential factor determining the in vitro calcium accessibility.

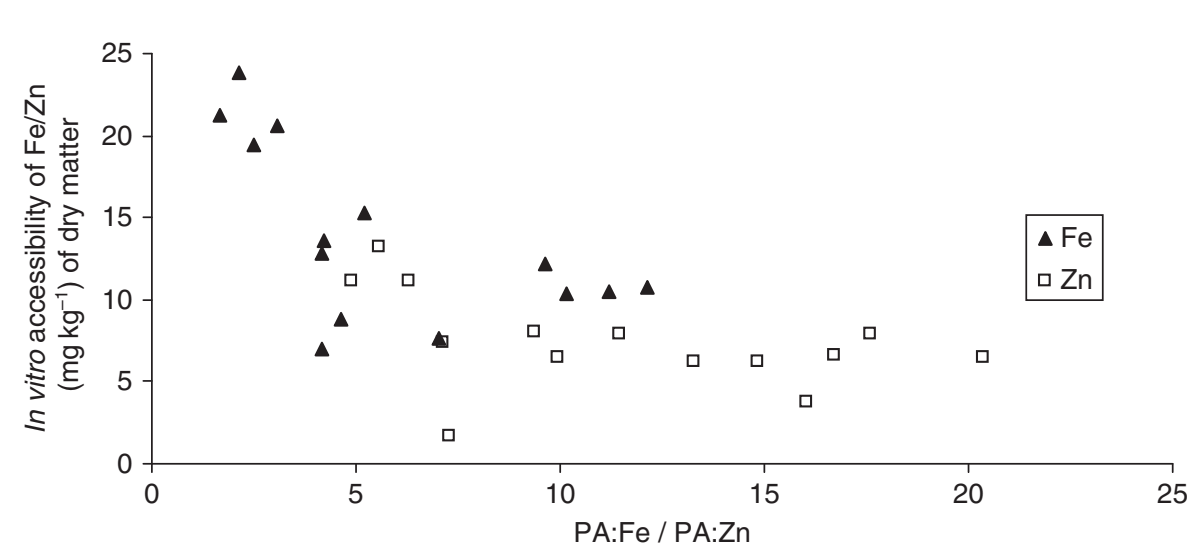

$$
\text { calcium accessibility. }
$$

Mung bean foods

1041

Figure 2.

In vitro accessibility of $\mathrm{Fe}$ and $\mathrm{Zn}$ as a function of PA:Fe and PA:Zn molar ratios, respectively 
$\mathrm{BFJ}$

116,6

1042
Contribution to recommended dietary allowance (RDA)

The percentage of recommended dietary intake of protein, iron, zinc and calcium covered by different mung bean food products for children of seven to nine years is given in Table VI (calculated on the fresh weight of product consumed on the basis of the recommendations of the Nutrition Society of India, Hyderabad). Different mung bean products $(100 \mathrm{~g})$ cover 12.0-59.5 per cent, 1.6-7.2 per cent, 1.4-9.1 per cent and 1.1-7.1 per cent of the RDA for protein, iron, zinc and calcium, respectively, for seven- to nine-year-old Indian children. There is a significant difference in the percentage of RDA covered for protein, iron, zinc and calcium between products. Percentage of RDA covered for protein is highest in the sweets, as well as snacks, except bhalle, which covered RDA in lower amounts than wadian, split dhal and khichadi. Halwa, burfi, dehulled split dhal and pakore cover relatively higher percentage of RDA for iron, whereas khichadi, whole dhal, split dhal and wadian cover relatively lower percentage RDA for iron.

\section{Conclusion}

Information on nutrients and anti-nutritional factors of traditional food products is important for food composition databases (Khalil, 2000), to know the nutritional intake of populations and to select foods for product and process design and development. In the case of mung bean products, it seems that fermented and germinated products

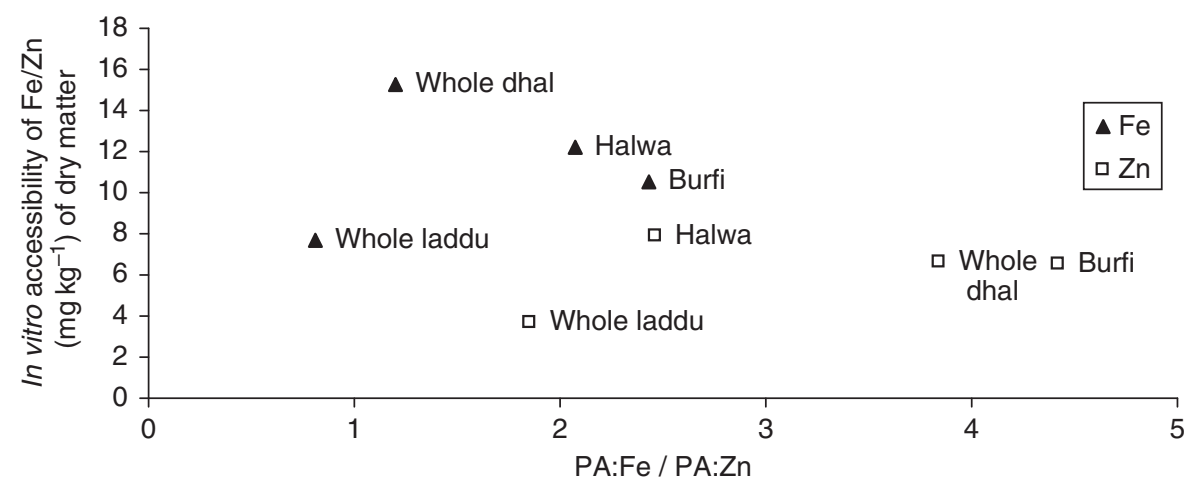

Note: As calculated by phytic acid assuming that all calcium present is bound to phytic acid

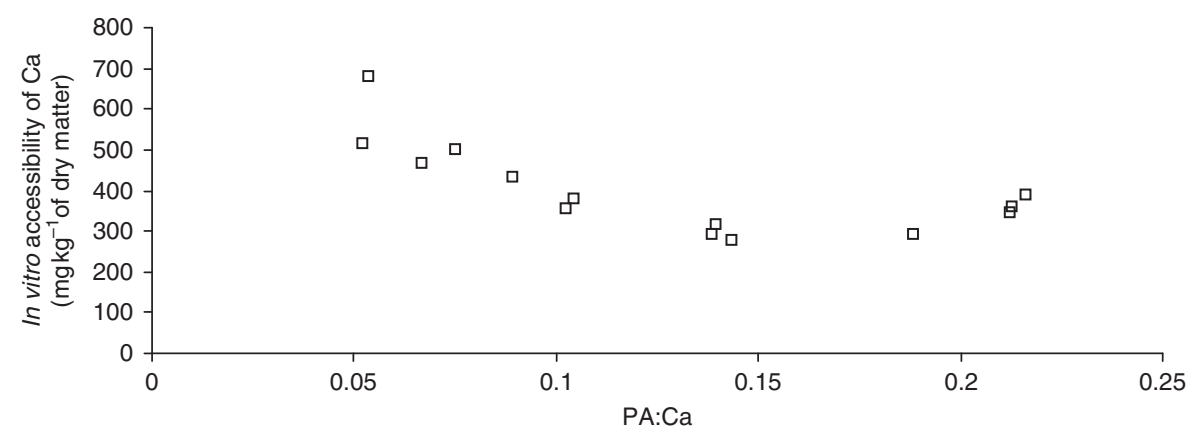

Figure 3.

In vitro accessibility of $\mathrm{Fe}$ and $\mathrm{Zn}$ as a function of PA:Fe and PA:Zn molar ratios, respectively, in split dhal, whole laddu, burfi and halwa

\section{Figure 4.}

In vitro calcium accessibility as a function of PA:Ca molar ratio 


\begin{tabular}{|c|c|c|c|c|c|c|}
\hline Food type & Products & $\%$ RDA protein & $\%$ RDA iron & $\%$ RDA zinc & $\%$ RDA calcium & ean \\
\hline \multirow[t]{3}{*}{ Dhals } & Whole dhal & 21.1 & 2.2 & 2.1 & 1.4 & \\
\hline & Split dhal & 12.1 & 1.7 & 1.4 & 1.1 & \\
\hline & Dehulled split dhal & 28.7 & 6.1 & 6.8 & 4.7 & \\
\hline \multirow[t]{4}{*}{ Sweets } & Whole laddu & 32.6 & 4.1 & 4.0 & 4.2 & \\
\hline & Dehulled split laddu & 36.6 & 5.7 & 6.9 & 4.1 & 1043 \\
\hline & Burfi & 48.3 & 6.1 & 7.5 & 5.6 & \\
\hline & Halwa & 59.5 & 7.2 & 9.2 & 5.4 & \\
\hline \multirow[t]{4}{*}{ Snacks } & Namkeen & 51.6 & 3.4 & 1.7 & 5.7 & \\
\hline & Papad & 47.4 & 4.6 & 7.6 & 7.1 & \\
\hline & Bhalle & 16.8 & 3.7 & 3.9 & 2.2 & Table VI. \\
\hline & Pakore & 35.4 & 6.5 & 7.5 & 3.4 & Percentage of \\
\hline \multirow[t]{3}{*}{ Others } & Wadian & 16.9 & 2.5 & 2.5 & 2.6 & recommended dietary \\
\hline & Khichadi & 14.0 & 1.7 & 2.4 & 1.2 & intake of protein, iron, \\
\hline & Sprouts & 26.2 & 5.8 & 4.6 & 2.7 & $\begin{array}{l}\text { zinc and calcium covered } \\
\text { by mung bean derived }\end{array}$ \\
\hline \multicolumn{6}{|c|}{$\begin{array}{l}\text { Notes: Calculated for } 100 \text { fresh weight on the basis of total protein and in vitro mineral accessibility. } \\
\text { aRDA used are } 29.5 \mathrm{~g} \text { protein, } 16 \mathrm{mg} \text { iron, } 8 \mathrm{mg} \text { zinc and } 600 \mathrm{mg} \text { calcium }\end{array}$} & $\begin{array}{l}\text { foods for children of } \\
\text { seven to nine years }\end{array}$ \\
\hline
\end{tabular}

have higher amounts of in vitro accessible minerals and lower anti-nutritional compounds as compared to fried ones. This indicates the possibility to improve the non-fermented foods like khichadi and whole dhal by incorporating these processing steps. However, due to multiple processing steps it is not clear which processing step has the largest impact on the in vitro mineral accessibility. Therefore, controlled experiments are needed to evaluate the relative impact of the different processing methods on the mineral accessibility in mung bean foods.

Moreover, other ingredients used in mung bean products seem to play a significant role in in vitro mineral accessibility, as some might be acting as mineral enhancers and others as inhibitors. Khichadi has low amounts of in vitro accessible minerals and other nutrients, and therefore it needs to be consumed with mineral-rich vegetables. Products with relatively high amounts of anti-nutrients, like whole and split dhal, can be consumed along with food products containing enhancers of mineral absorption in vivo, like ascorbic acid (Jin et al., 2009). In terms of in vitro mineral accessibility, dehulled split mung bean grains are a better ingredient for mung bean foods than whole or split mung bean grains. In vitro mineral accessibility in mung bean products can also be increased by using mung bean varieties with high levels of total minerals, like iron and zinc, and lower levels of anti-nutritional compounds like phytic acid and polyphenols.

\section{References}

Abdullah, A., Baldwin, R.E. and Minor, H. (1984), "Germination effects on flatus causing factors and anti-nutrients of mung beans and two strains of small-seeded soybeans", Journal of Food Protection, Vol. 47 No. 6, pp. 441-444.

AOAC (1990), Official Methods of Analysis, 15th ed., Association of Official Analytical Chemists, Washington, DC.

AOAC (1995), Official Methods of Analysis, 16th ed., Association of Official Analytical Chemists, Washington, DC.

Barakoti, L. and Bains, K. (2007), "Effect of household processing on the in vitro bioavailability of iron in mung bean (Vigna radiata)", Food and Nutrition Bulletin, Vol. 28 No. 1, pp. 18-22. 
$\mathrm{BFJ}$ 116,6

1044

Chitra, U., Vimala, V., Singh, U. and Geervani, P. (1995), "Variability in phytic acid content and protein digestibility of grain legumes", Plant Foods for Human Nutrition, Vol. 47 No. 2, pp. 163-172.

Crea, F., De Stefano, C., Milea, D. and Sammartano, S. (2008), "Formation and stability of phytate complexes in solution", Coordination Chemistry Reviews, Vol. 252 Nos 10-11, pp. 1108-1120.

Dahiya, P.K., Linnemann, A.R., Nout, M.J.R., van Boekel, M.A.J.S. and Grewal, R.B. (2013), "Nutrient composition of selected newly bred and established mung bean varieties", LWT - Food Science and Technology, Vol. 54 No. 1, pp. 249-256.

Dahiya, P.K., Linnemann, A.R., Nout, M.J.R., van Boekel, M.A.J.S., Khetarpaul, N. and Grewal, R.B. (2014), "Mung bean: technological and nutritional potential", Critical Reviews in Food Science and Nutrition, doi:10.1080/10408398.2012.671202 (in press).

Davidsson, L., Walczyk, T., Zavaleta, N. and Hurrell, R. (2001), "Improving iron absorption from a Peruvian school breakfast meal by adding ascorbic acid or $\mathrm{Na}_{2}$ EDTA", American Journal of Clinical Nutrition, Vol. 73 No. 2, pp. 283-287.

Davies, N.T. and Reid, H. (1979), "An evaluation of the phytate, zinc, copper, iron and manganese contents of, and $\mathrm{Zn}$ availability from, soya based textured vegetable protein meat-substitutes or meat-extenders", British Journal of Nutrition, Vol. 41 No. 3, pp. 579-589.

Ghavidel, R.A. and Prakash, J. (2007), "The impact of germination and dehulling on nutrients, antinutrients, in vitro iron and calcium bioavailability and in vitro starch and protein digestibility of some legume seeds", LWT-Food Science and Technology, Vol. 40 No. 7, pp. 1292-1299.

Grover, D.K., Weinberger, K. and Shanmugasundaram, S. (2004), Production and Consumption Status of Mungbean in India, Agricultural Situation in India, Ministry of Agriculture, Government of India, Delhi.

Hallberg, L., Brune, M. and Rossander, L. (1989), "Iron absorption in man: ascorbic acid and dose-dependent inhibition by phytate", American Journal of Clinical Nutrition, Vol. 49 No. 1, pp. 140-144.

Jin, F., Frohman, C., Thannhauser, T.W., Welch, R.M. and Glahn, R.P. (2009), "Effects of ascorbic acid, phytic acid and tannic acid on iron bioavailability from reconstituted ferritin measured by an in vitro digestion-Caco-2 cell model”, British Journal of Nutrition, Vol. 101 No. 7, pp. 972-981.

Jood, S., Bishnoi, S. and Sehgal, S. (1998), "Effect of processing on nutritional and antinutritional factors of moongbean cultivars", Journal of Food Biochemistry, Vol. 22 No. 3, pp. 245-257.

Khalil, J.K. (2000), "Food composition activities in developing countries: SAARCFOODS perspective", Journal of Food Composition and Analysis, Vol. 13 No. 4, pp. 669-684.

Kim, H.S. and Zemel, M.B. (1986), "In vitro estimation of the potential bioavailability of calcium from sea mustard (Undaria pinnatifida), milk, and spinach under simulated normal and reduced gastric acid conditions”, Journal of Food Science, Vol. 51 No. 4, pp. 957-959.

Lindsay, W.L. and Norwell, W.A. (1978), "Development of a DTPA soil test for zinc, iron, manganese, and copper", Soil Science Society of America Journal, Vol. 42 No. 3 pp. 421-428.

Manu and Khetarpaul, N. (2006), "Food consumption pattern of Indian rural preschool children (four to five years)", British Food Journal, Vol. 108 No. 2, pp. 127-140.

Morris, E.R. and Ellis, R. (1980), "Bioavailability to rats of iron and zinc in wheat bran: response to low-phytate bran and effect of the phytate/zinc molar ratio", Journal of Nutrition, Vol. 110 No. 10, pp. 2000-2010.

Panse, Y.G. and Sukhatme, P.V. (1961), Statistical Methods of Agricultural Coworkers, 2nd ed., Indian Council of Agricultural Research, New Delhi. 
Parthasarathy, V.A., Chempakam, B. and Zachariah, T.J. (2008), Chemistry of Spices, CAB International, Oxfordshire.

Pradeep, K.U., Geervani, P. and Eggum, B.O. (1993), "Common Indian spices: nutrient composition, consumption and contribution to dietary value", Plant Foods for Human Nutrition, Vol. 44 No. 2, pp. 137-148.

Pushpanjali and Khokhar, S. (1995), "The composition of Indian foods - mineral composition and intakes of Indian vegetarian populations", Journal of Science of Food and Agriculture, Vol. 67 No. 2, pp. 267-276.

Rao, B.S.N. and Prabhavathi, T. (1978), "An in vitro method for predicting the bioavailability of iron from foods", American Journal of Clinical Nutrition, Vol. 31 No. 1, pp. 169-175.

Sattar, A., Durrani, S.K., Mahmood, F., Ahmad, A. and Khan, I. (1989), "Effect of soaking and germination temperatures on selected nutrients and anti-nutrients of mung bean", Food Chemistry, Vol. 34 No. 2, pp. 111-120.

Singh, U. and Jambunathan, R. (1981), "Studies on desi and kabuli chickpea (Cicer arietinum L.) cultivars: levels of protease inhibitors, levels of polyphenolic compounds and in vitro protein digestibility", Journal of Food Science, Vol. 46 No. 5, pp. 1364-1367.

Swain, T. and Hills, W.E. (1959), "The phenolic constituents of Prunus domestica. I- The quantitative analysis of phenolic constituents", Journal of the Science of Food and Agriculture, Vol. 10 No. 1, pp. 63-68.

Venkatachalam, M. and Sathe, S.K. (2006), "Chemical composition of selected edible nut seeds", Journal of Agricultural and Food Chemistry, Vol. 54 No. 13, pp. 4705-4714.

Wyatt, J.C. and Triana-Tejas, A. (1994), "Soluble and insoluble Fe, Zn, Ca, and phytates in foods commonly consumed in Northern Mexico", Journal of Agricultural and Food Chemistry, Vol. 42 No. 10, pp. 2204-2209.

\section{Further reading}

National Institute of Nutrition, Hyderabad (2009), Nutrient Requirements and Recommended Dietary Allowances for Indians, National Institute of Nutrition, Hyderabad, pp. 156-227.

\section{About the authors}

Pradeep Kumar Dahiya completed his BSc in Biological Sciences at the Maharishi Dayanand University, Rohtak, India in 2003. Next he completed a BSc in Education in 2004. In 2006 he obtained his MSc Degree in Food Science and Technology from the Centre of Food Science \& Technology, CCS Haryana Agricultural University, Hisar, India. In 2007 he obtained a PhD Research Grant from the Wageningen University through the Interdisciplinary Research and Education Fund (INREF), to undertake his PhD Research at the Wageningen University, the Netherlands. Since April 2007 he is researching the topic of redesigning mung bean foods.

M.J.R. Nout is an Externe Medewerker in the Food Microbiology Laboratory at the WU Agrotechnology \& Food Sciences. His areas of expertise are foods, development cooperation, fungi and cereal products.

Martinus A. van Boekel is a Professor at the Education Institute of the Wageningen University, specialising in Food Sciences, particularly Food Quality and Safety and Food Technology.

Dr Neelam Khetarpaul obtained a BSc (1976), an MSc (1978) and a PhD (1988) Degrees in Food Science \& Nutrition at the Department of Foods and Nutrition, CCS Haryana Agricultural University, Hisar, India. Since 1979, she is teaching and conducting research in the areas of foods and nutrition. She worked as Dean, College of Home Science from 6 May 2006 to 5 May 2010. She supervised more than $27 \mathrm{MSc}$ and $\mathrm{PhD}$ Students and published 234 research articles and 22 books. She is the life member of many food and nutrition-related organisations. 
$\mathrm{BFJ}$

116,6

1046
Dr Raj Bala Grewal is the Dean of Post Graduate Studies at CCS Haryana Agricultural University, Hisar, India. She obtained a BSc (1977), an MSc (1980) and a PhD (1991) Degrees in Foods \& Nutrition at the Department of Foods and Nutrition, CCS Haryana Agricultural University, Hisar, India. Since 1995, she is teaching and conducting research in the areas of food science and technology. She supervised three $\mathrm{PhD}$ students and published 68 research articles and six books. She is life member of many food and nutrition-related organisations.

Dr Anita Linnemann in 1985, she obtained a double Master Degree from the Wageningen University in Tropical Agriculture and Food Technology. She completed her $\mathrm{PhD}$ thesis, entitled Ecophysiology of bambara groundnut (Vigna subterranea (L.) Verdc.), in 1994. Since 1995 she is a staff member of the Food Quality and Design of the Wageningen University. Her expertise is in consumer-oriented food product development with special attention to sustainability issues. Her work in education and research is characterised by an interdisciplinary approach and the integration of natural and social sciences. At present she is supervising $\mathrm{PhD}$ students from Benin, Ecuador, India, Zimbabwe and Kenya, who are working on foods from cowpea, mungbean, lupin, pineapple, baobab, banana, cashew, shea and dye sorghum. Dr Anita Linnemann is the corresponding author and can be contacted at: anita.linnemann@wur.nl

To purchase reprints of this article please e-mail: reprints@emeraldinsight.com Or visit our web site for further details: www.emeraldinsight.com/reprints 